\title{
DAMPAK PERKEMBANGAN KAWASAN WISATA PANTAI LIANG TERHADAP MASYARAKAT (Studi Deskriptif pada Masyarakat Desa Liang Kecamatan Salahutu Kabupaten Maluku Tengah)
}

\author{
Syamsuddin, Pebrywati Watimury, Adianto \\ Dosen Fakultas Dakwah Ushuludin IAIN Ambon \\ *) E-mail: Syamsuddin_amb@yahoo.co.id
}

\begin{abstract}
The impact of Tourist development in tourism areas on an area need balancing of environmental and social interactions, this balance can increase the number of visitors to the tourist area and directly increase the income of the area itself. This research has purpose to know about the impact of regional development in Liang beach as a tourism place to local people who live in Liang village, Salahutu District, Central Molluca Regency. The object of this research is the people who stay in Liang village. The technique of Data collection through interviews and observation. The results of the research, the development of Liang beach as a tourism place has impact on people's economic.the income of food vendors are increase, games rental service, billing entrance, rental of tents and billing services WC, well established community social interaction with visitors and the level of environmental pollution on the development of tourist areas in Liang beach.
\end{abstract}

Keywords: The Impact of Tourist Development, Tourism place, Liang beach

\section{ABSTRAK}

Dampak perkembangan kawasan wisata pada suatu daerah memerlukan adanya keseimbangan lingkungan dan interaksi sosial masyarakat, adanya keseimbangan dapat meningkatkan jumlah pengunjung pada kawasan wisata tersebut dan secara langsung meningkatkan pendapatan pada suatu daerah. Penelitian ini bertujuan mengetahui dampak perkembangan kawasan pantali Liang terhadapa Masyarakat Desa Liang Kecematan salahutu Kabupaten Maluku Tengah. Objek dalam penelitian ini adalah masyarakat yang terlibat langsung dalam kawasan wisata pantai Liang. Teknik pengumpulan data melalui wawancara dan observasi terstruktur. Hasil penelitian, perkembangan kawasan wisata pantai Liang berdampak pada ekonomi masyarakat yaitu peningkatan pendapatan pedagang makanan,penyewaan jasa permainan, penagihan pintu masuk, penyewaan tenda dan penagihan jasa WC, interkasi sosial masyarakat yang terjalin baik dengan pengunjung dan adanya tingkat pencemaran lingkungan pada perkembangan kawasan wisata pantai Liang.

Kata kunci: Dampak Perkembangan, Kawasan Wisata , Pantai Liang

\section{PENDAHULUAN}

Indonesia sebagai negara kepulauan terbesar di dunia yang terdiri dari 17.508 pulau dengan garis pantai sepanjang $81.000 \mathrm{~km}$ dan luas laut sekitar 3,1 juta $\mathrm{km}^{2}$, merupakan potensi sumber daya pesisir yang besar sebagai modal dalam upaya meningkatkan taraf hidup dan kesejahteraan masyarakat termasuk masyarakat pesisir. Undang-Undang Nomor 9 Tahun 1990, modal tersebut dapat dimanfaatkan melalui pembangunan kepariwisataan wilayah pesisir, sebagaimana tujuan kepariwisataan Indonesia yang diarahkan untuk meningkatkan pendapatan nasional dalam rangka meningkatkan kesejahteraan dan kemakmuran rakyat, memperluas dan memeratakan kesempatan berusaha dalam lapangan-pangan kerja, dan mendorong pembangunan daerah.

Pembangunan wilayah pesisir dan laut bertujuan untuk meningkatkan kesejahteraan masyarakat. Masyarakat pesisir sebagai pelaku dan tujuan pembangunan wilayah pesisir dan lautan harus mendapatkan manfaat terbesar dari kegiatan pembangunan tersebut. Demikian pula dalam pembangunan wilayah pesisir untuk kegiatan pariwisata harus dilakukan dengan mengedepankan upaya deversifikasi usaha dan memberikan kesempatan kerja bagi masyarakat pesisir disamping usaha perikanan. Pariwisata seperti yang ditegaskan oleh Wahab adalah salah satu dari industri gaya baru mempunyai dimensi-dimensi dan persepsi-persepsi yang 
bervariasi mampu menyediakan pertumbuhan ekonomi yang cepat dalam hal kesempatan kerja, pendapatan, taraf hidup dan dalam mengaktifkan sektor produksi lain di daerah tujuan wisatawan.

Pembangunan wilayah pesisir dan laut bertujuan untuk meningkatkan kesejahteraan masyarakat. Masyarakat pesisir sebagai pelaku dan tujuan pembangunan wilayah pesisir dan lautan harus mendapatkan manfaat terbesar dari kegiatan pembangunan tersebut. Demikian pula dalam pembangunan wilayah pesisir untuk kegiatan pariwisata harus dilakukan dengan mengedepankan upaya deversifikasi usaha dan memberikan kesempatan kerja bagi masyarakat pesisir disamping usaha perikanan. Pariwisata seperti yang ditegaskan oleh Wahab adalah salah satu dari industri gaya baru mempunyai dimensi-dimensi dan persepsi-persepsi yang bervariasi mampu menyediakan pertumbuhan ekonomi yang cepat dalam hal kesempatan kerja, pendapatan, taraf hidup dan dalam mengaktifkan sektor produksi lain di daerah tujuan wisatawan. ${ }^{1}$

Kabupaten Maluku Tengah termasuk wilayah pesisir Utara Barat, mempunyai garis pantai sepanjang $9 \mathrm{~km}$ dengan kondisi geografis wilayah pesisir di Kabupaten Maluku Tengah khususnya desa Liang dengan pantai pasir putih berbatu memiliki nilai ekonomi dan banyak berkembang menjadi kawasan wisata. Potensi wilayah pesisir yang dimiliki ini dikembangkan oleh Pemerintah Daerahuntuk kegiatan pariwisata dan menjadikan sektor pariwisata sebagai salah satu sektor andalan (sektor ekonomi basis) guna meningkatkan perekonomian masyarakat dan peningkatan pendapatan asli daerah. Kebijakan ini dilakukan karena sektor pariwisata dapat mendatangkan

${ }^{1}$ Salah Wahab, Manajemen Kepariwisataan, Alih BahasaFans Gromang. Jakarta: Pradnya Paramita, 2003. H.5 devisa dari pengeluaran wisatawan, sektor ekonomi basis merupakan sektor-sektor yang hasil produksinya dapat dijual keluar daerah atau mendatangkan uang dari luar daerah. Beberapa wilayah pesisir yang selama ini dikembangkan menjadi kawasan wisata antara lain: Pantai Liang, Pantai Sahapori Tial, dan Pantai Pasir Panjang Suli.

Dengan demikian, maka keberhasilan pengembangan suatu wilayah maupun kawasan dapat diukur dari beberapa faktor, salah satunya adalah dampak atau pengaruh positif terhadap masyarakat. Demikian pula keberhasilan dalam pengembangan kawasan wisata di wilayah pesisir yang diukur dari dampak positif yang diberikan terhadap peningkatan kesejahteraan masyarakat dan kelestarian lingkungan pesisir khususnya Pantai Liang Kecamatan Salahutu Kabupaten Maluku Tengah.

\section{PEMBAHASAN}

Provinsi Maluku, di Indonesia Bagian Timur memiliki potensi pariwisata yang sangat kaya dengan berbagai obyek wisata, baik berupa panorama alam laut maupun darat. Bahkan dibeberapa daerah, pariwisatanya sudah terkenal sampai mancanegara, seperti Taman Laut Manuala, Pantai Pasir Panjang, Pintu KotaAmbon, dan juga termasuk pantai Hunimua (Pantai Liang). Dalam Undang-Undang Nomor 9 Tahun 1990 dinyatakan bahwa yang dimaksud dengan wisata adalah kegiatan perjalanan atau sebagian dari kegiatan tersebut yang dilakukan secara sukarela serta bersifat sementara untuk menikmati objek dan daya tarik wisata. Kawasan wisata merupakan salah satu tempat berkumpul dengan keluarga dan orang-orang terdekat yang menghabiskan waktu setelah beberapa hari melakukan aktifitas.

Kepariwisataan Indonesia yang berkembang, selain kegiatan "domestic tourism” yaitu lalu lintas wisatawan di dalam 
negeri, juga berkembang kegiatan "foreign tourism" termasuk di dalamnya lalu lintas wisatawan dari luar negeri ke dalam negeri (in bound tourism), maupun dari dalam negeri ke luar negeri (out going tourism). kegiatan kepariwisataan yang ditandai dengan keluarnya warga negara sendiri yang bepergian keluar negeri sebagai wisatawan. ${ }^{2}$

\section{a. Peningkatan Ekonomi Kawasan Pantai Liang}

Dampak pariwisata adalah perubahanperubahan yang terjadi terhadap lingkungan hidup sebelum adanya kegiatan pariwisata dan setelah adanya kegiatan pariwisata baik langsung maupun tidak langsung yang berupa dampak fisik dan non fisik. Adapun masyarakat sebagai salah satu komponen lingkungan hidup juga mengalami perubahan-perubahan. Dampak non fisik terhadap masyarakat yang ditimbulkan yaitu perubahan kondisi sosial ekonomi masyarakat. Kemudian dampak fisik terhadap, masyarakat yang terjadi yaitu perubahan lingkungan fisik dan fungsi permukiman. Tingkat perkembangan kawasan dalam sektor perekonomian, merupakan dampak positif bagi masyarakat sekitar, kurangnya pengunjung kawasan wisata merupakan dampak negatif yang dirasakan masyarakat, berakibat pada pendapatan, pendapan yang melonjak yang dirasakan oleh masyarakat berperang penting dalam pemenuhan kebutuhan keluarga, tingkat pendidikan anak dan kebutuhan sandang keluarga. Pendapatan masyarakat yang terlibat langsung dalam kawasan wisata baik pedangan asongan, jasa wahana permainan, jasa Wc umum, dan penagihan biaya masuk kawasan wisata berbeda dengan hari-hari biasanya.

${ }^{2}$ UE. Wardhani dkk, Usaha Jasa Pariwisata, Direktorat Pembinaan Sekolah Menengah Kejuruan, Jilid II.h.256
Bengen (2002) Aktivitas ekonomi yang dilakukan bertujuan untuk meningkatkan kesejahteraan masyarakat dengan ketergantungannya terhadap kondisi lingkungan dan sumber daya alam yang ada di sekitarnya, pemerintah dalam pengelolaan lingkungan hidup dan sumberdaya alam, lembaga sosial aktivitas, ekonomi pendidikan, kesehatan dan lain-lain

\section{b. Dampak Lingkungan Fisik dalam Kawasan Pantai Liang}

Berbagai Kegiatan manusia hampir selalu menghasilkan pencemaran lingkungan fisik, timbulnya pencemaran yang dihasilkan berasal dari kebutuhan

manusia, pencemaran yang tidak terkontrol dapat menimbulkan pencemaran yang lebih banyak dan meluas pada kawasan wisata Pantai Liang.

Banyak faktor yang menjadi penyebab menurunya kualitas lingkungan pantai diantaranya yaitu rendahnya pengetahuan dan tingkat pendidikan dan pengetahuan masyarakat tentang lingkungan, disamping itu dalam pengelolaan kawasan wisata kebiasaan hidup pengunjung dapat membuang sampah tidak pada tempatnya. pencemaran lingkungan dapat diakibatkan oleh masyarakat pada lingkungan itu sendiri, dilihat lebih jauh peningkatan kawasan wisata pantai, lingkungan mempunyai peran dalam peningkatan dan penurunan pengunjung pada daerah wisata, berwawasan lingkungan perlu bagi masyarakat untuk menciptakan pembangunan berwawasan lingkungan yang berkelanjutan (Sustainable), faktor lingkungan adalah harga jual bagi pengunjung wisata pesisir. ${ }^{3}$

Abdurahman (1990) Tindakan manusia terhadap lingkungan dilakukan berdasarkan keputusan yang berasal dari persepsi yang 
bersumber atas dua hal penting tentang perilaku manusia yaitu: (1) perilaku yang merupakan fungsi dari orang dan situasinya, (2) orang tidak hanya akan beraksi pada ciri objektif suatu aktivitas, tetapi juga pada penafsiran objektif sendiri dengan kata lain sikap merupakan komponen kognitif yang saling berinteraksi sehingga menghasilkan suatu perilaku tertentu terhadap obyek.

Dalam kaitannya dengan lingungan hidup, perilaku manusia dapat menentukan keberlanjutan kondisi lingkungan. Perilaku pengelolaan lingkungan hidup, bertujuan untuk memenuhi kebutuhan hidup saat ini tanpa merusak atau menurunkan kemampuan generasi mendatang untuk memenuhi kebutuhan hidupnya. Dampak, dampak tersebut dapat berupa dampak positif maupun dampak negatif. Dampak positif dapat berupa konservasi kawasan alam, konservasi lokasi sejarah dan arkeologi serta bentukan khas, peningkatan kualitas lingkungan, peningkatan infrastruktur, peningkatan kesadaran lingkungan. Sedangkan dampak negatifnya dapat berupa polusi air, polusi udara, polusi suara, polusi pemandangan, masalah pengolahan limbah, penurunan ekologi, bencana lingkungan, kerusakan situs-situs bersejarah dan arkeologi, serta permasalahan guna lahan. Pesisir merupakan salah satu lokasi yang sangat baik sebagai objek daya tarik wisata. Pariwisata pesisir merupakan kombinasi antara komponen daratan dan laut yang menyajikan keindahan berupa air laut, pantai, keanekaragaman biota laut maupun darat. ${ }^{4}$

\section{c. Dampak Sosial dalam Kawasan Pantai Liang}

Dalam pengembangan kawasan pantai banyak dampak yang dijumpai salah satunya dampak sosial bagi masyarakat sekitar dan pengunjung System sosial adalah suatu pola interaksi social yang terdiri dari komponen- komponen sosial yang teratur dan melembaga (institutionalized). Adapun sistem sosial

Hubungan yang bersifat positif ini dapat berupa hubungan kerja sama sedangkan hubungan yang bersifat negatif ini dapat berupa persaingan, bahkan memungkinkan terjadinya konflik. Mengingat banyaknya pedagang yang berjualan di kawasan Ketep Pass, maka kemungkinan terjadi interaksi sosial yang berupa kerjasama, persaingan, maupun konflik tentunya sangat besar dan sering terjadi.

Manusia merupakan makhluk sosial yang tidak dapat hidup tanpa bantuan orang lain. Oleh karena itu manusia perlu berinteraksi dengan manusia lainnya tanpa adanya interaksi sosial, tidak mungkin ada kehidupan bersama. Interaksi sosial merupakan hubungan-hubungan sosial yang dinamis menyangkut hubungan antara orang per orangan, antara kelompok dan kelompok manusia, maupun antara orang per oramgan dengan kelompok manusia. Suatu interaksi sosial tidak akan mungkin terjadi apabila tidak memenuhi 2 syarat, yaitu adanya kontak sosial dan komunikasi. Kontak sosial adalah hubungan antara satu pihak dengan pihak lain yang merupakan awal terjadinya interaksi sosial, dan masing-masing pihak saling bereaksi meski tidak harus bersentuhan secara fisik. Kontak sosial dapat terjadi walau dua pihak hanya saling berhadapan atau bertatap muka.

Syarat kedua adanya interaksi sosial adalah adanya komunikasi sosial. Komunikasi adalah seorang memberikan tafsiran pada perilaku orang lain (berwujud pembicaraan, gerak-gerik badaniyah atau sikap). Perasaanperasaan apa yang ingin disampaikan oleh orang tersebut. Orang yang bersangkutan kemudian memberikan reaksi terhadap perasaan yang ingin disampaikan oleh orang lain tersebut. Adanya komunikasi tersebut, sikap-sikap, dan perasaan-perasaan satu kelompok manusia atau orang per seorangan dapat diketahui oleh 
kelompok-kelompok lain atau orang lain. Hal itu kemudian merupakan bahan untuk menentuan reaksi apa yang akan dilakukannya ${ }^{5}$

Interaksi sosial yang dilakukan oleh manusia dalam lingkungan masayarakat merupakan perwujudan dari hakikat manusia yang merupakan mahlukh sosial. Interaksi yang berlangsung dalam kawasan wisata menandakan individu satu dengan individu yang lain saling membutuhkan baik dalam konteks menanyakan keadaan sekitar lokasi kawasan wisata.

Interaksi sosial dapat terjadi dalam kehidupan bermasyarakat, karena pada dasaranya manusia hidup saling membutuhkan satu sama lain begitu juga dengan keadaan yang terjadi dalam kawasan wisata Pantai Hunimua (Pantai Liang), saling membutuhkan adalah hakikat hidup bermasyarakat keadaan terlihat sangat jelas pada kawasan wisata pantai Hunimua (Pantai Liang) baik interkasi sosial dengan sesame pengunjung dari daerah lain maupun interaksi antara pengunjung dengan masyarakat yang terlibat langsung dalam kawasan wisata pantai liang, baik pedagang asongan, jasa penyewaan arena permainan, penagihan pintu masuk, maupun penyewaan $\mathrm{Wc}$ umum.

\section{PENUTUP}

Berdasarkan hasil penelitian yang dilaksanakan melalui wawancara dengan masyarakat yang terlibat langsung dengan kawasan wisata pantai Hunimua (Pantai Liang) yaitu dengan Pedagang asongan, Penyewaan Jasa Permainan, Penagihan Pintu Masuk dan Penyewaan Wc Umum terkait dengan Perkembangan kawasan wisata pantai Hunimua (Pantai Liang) dan Observasi terstruktur yang dilaksanakan maka jumlah pengunjung akan meningkat dari hari-hari biasanya yaitu hari-hari Libur pekan dan hari-hari libur keagamaan dapat membentuk tiga mata rantai dalam kawasan wisata pantai Liang yaitu terciptanya komunikasi sosial yang baik antara pengunjung dengan pengunjung dan pengunjung dan masyarakat, perokonomian keluarga meningkat dengan adanya pendapatan yang didapatkan dalam peningkatan kawasan wisata dan Tingkat pencemaran Lingkungan meningkat.

Pengunjung akan merasa nyaman bila mana interaksi sosial yang ditawarkan oleh masyarakat berjalan dengan baik tanpa merubah adat dan istiadat masayarakat setempat, dengan adanya interaksi sosial yang baik, didukung dengan suasana yang ada pada pantai liang ikut mendukung. Maka pengunjung makin tertarik datang kearena wisata pantai liang dan secara langsung meningkatkan pendapatan pedagang, penyewaan jasa permainan, pendapatan biaya pintu masuk dan penyewaan Wc umum meningktan dan hal ini dapat meningkatkan perekonomian keluarga.

1. Interaksi sosial yang ada dalam kawasan pantai Liang dapat terlihat dengan adanya komonikasi yang baik antara pengunjung dan masyarakat

2. Peningkatan pendapatan dari berkembangnya kawasan wisata pantai Liang

3. Tingkat pencemaran Lingkungan makin tinggi

\section{DAFTAR PUSTAKA}

Indah Sri Pinasti, Fenomena sosiologi obyek wisata sejarah di Yogyakarta:suatu kajian tentang sosiologi pariwisata.

Lexy J. Moleong, Metodologi Penelitian Kualitatif, Bandung: Remaja Rosdakarya, 2004.

Pitana dan Gayatri Pitana, I Gde dan Gayatri, Putu G. Sosiologi Pariwisata, Yogyakarta : Andi Offset, 2005. 
Sugiyono, Metode Penelitian Kuantitatif dan Kualitatif dan $R$ \& $D$, Bandung: CV. Alfabeta, 2512.

UE. Wardhani dkk, Usaha Jasa Pariwisata,

Direktorat Pembinaan Sekolah Menengah Kejuruan, Jilid II.

Wahab, Salah, Manajemen Kepariwisataan, Alih BahasaFans Gromang. Jakarta: Pradnya Paramita, 2503.

Yoni Hermawan, Hubungan Antara Tingkat Pendidikan dan Presepsi Dengan Perilaku Ibu Rumah Tangga Dalam Pemeliharaan Kebersihan Lingkungan, Jurnal. Pendidikan ekonomi FKIP Universitas Siliwangi

Zulmiro Pinto, Kajian Perilaku Masyarakat Pesisir yang Mengakibatkan Kerusakan Lingkungan (Studi Kasus di Pantai Kuwaru, Desa Poncosari, Kecamatan Srandakan, Kabupaten Bantul, Provinsi $D I Y)$ Jurnal Wilayah dan Lingkungan. 